\title{
THE GENDERED
}

\section{IMPACT OF IMF}

\section{POLICIES IN MENA}

The case of Egypt, Jordan and Tunisia 
This paper takes a closer look at the gendered impact of conventional macroeconomic policies supported by the International Monetary Fund in its loan programmes for Egypt, Jordan and Tunisia since 2012. It calls on the IMF to build on its ongoing efforts to operationalize gender equality, and to go beyond policies of encouraging women's labour force participation, to consider both productive and reproductive spheres and to integrate a gender perspective in the design of its programmes and policies. The paper also addresses the impact of these policies on poverty and inequality.

(C) Oxfam International October 2019

This paper was written by Nabil Abdo. Oxfam acknowledges the assistance of Chiara Mariotti, Chafik Ben Rouine, Farah Kobaissy, Heba Khalil, Nadia Daar and Omar Ghannam, as well as Mahinour El-Badrawi and Kate Donald from the Center of Economic and Social Rights (CESR), in its production. It is part of a series of papers written to inform public debate on development and humanitarian policy issues.

For further information on the issues raised in this paper please email advocacy@oxfaminternational.org

This publication is copyright but the text may be used free of charge for the purposes of advocacy, campaigning, education, and research, provided that the source is acknowledged in full. The copyright holder requests that all such use be registered with them for impact assessment purposes. For copying in any other circumstances, or for re-use in other publications, or for translation or adaptation, permission must be secured and a fee may be charged. Email policyandpractice@oxfam.org.uk.

The information in this publication is correct at the time of going to press.

Published by Oxfam GB for Oxfam International under ISBN 978-1-78748-514-3 in October 2019. DOI: 10.21201/2019.5143

Oxfam GB, Oxfam House, John Smith Drive, Cowley, Oxford, OX4 2JY, UK. 


\section{EXECUTIVE SUMMARY}

The IMF has made important and real strides towards recognizing the need to address gender and economic inequalities. That the IMF is saying these issues are 'macro-critical' and therefore impact on growth and stability is an important evolution in its analysis. The concern that this paper lays out is the gap between the thinking of the IMF in its research and its actual operations in countries, which have yet to properly catch up with this new thinking. As we examine how that analysis plays out in IMF operations, we see some notable efforts; however, gender and economic inequality are often treated as add-ons, and the core policies the IMF insists on with governments have changed very little.

This paper examines to what extent the IMF has been able to integrate gender into its loan programmes in the Middle East and North Africa (MENA) region. Our analysis finds that despite the region recording one of the highest income inequality levels in the world, as well as having a notorious record on gender inequalities, recent IMF interventions missed the mark in using policy solutions to help address these challenges. Indeed, IMF loan programmes with Egypt, Jordan and Tunisia might have exacerbated these inequalities through their supported economic reform programmes since 2012 with the Fund, which have provided a combined \$17.4bn in loans.

We find that in these three countries, while the IMF has done better at recognizing gender inequality, this has not yet been reflected enough in its policy and programmes. It has failed to systematically integrate gender concerns into the design of its programmes and has focused fairly narrowly on measures to increase women's participation in paid work. As a result, the gendered impact of macroeconomic policies supported by the IMF has been seemingly ignored, and women in the MENA region have paid the price.

The austerity policies supported by the IMF have contributed to a decrease in social spending and an increase in poverty, leaving women the most affected. For example, comparing data from the year before the IMF programmes began in each country with the most recent data available we find that:

- In Tunisia, between 2011 and 2019, the share of funding for education in the public budget decreased from $26.6 \%$ to $17.7 \%$, and the share of health expenditures declined from $6.6 \%$ in 2011 to $5 \%$ in 2019.

- In Jordan, public health spending has declined from 5.6\% of GDP in 2011 to $3.4 \%$ in 2016 , while out of pocket expenditures on health have increased.

These cuts in public spending are likely to be compensated for by an increase in women's unpaid care work, reducing their time for paid work, leisure and rest. This consideration was notably absent in the programmes examined. In Egypt, women are already spending an average of 30.25 hours per week on unpaid work, proving this issue should not be overlooked, and that it has serious macroeconomic implications.

This situation is compounded by the systematic cut in fuel and energy subsidies without adequate efforts to avoid the devastating effects on poor people caused by even slight changes in prices. 
In Egypt, fuel and energy subsidy reforms combined with high inflation as a result of currency floating has led to a cumulative increase in electricity bills for the poorest people and middle-income families by $218 \%$ and $271 \%$ respectively since 2011. Removing subsidies in an irresponsible way can have adverse effects on women, especially when it comes to fuel products which are used for cooking, such as liquified petroleum gas (LPG), which has increased in price by $712 \%$ since 2014.

While in exceptional circumstances the IMF has supported an increase in corporate and income tax, such as in Jordan, it has consistently promoted an increase in indirect taxes like VAT or a removal of VAT exemptions on basic goods in all three countries - measures that have been shown to increase both economic and gender inequality.

The IMF calls for an increase in women's labour force participation in Egypt and Tunisia, but it has missed the opportunity to promote policies to address the severe lack of decent work conditions. In fact, when women do engage in paid work, the inequality in the region and in these countries is so deeply gendered they are often found in the lowest paid jobs with the least job security. The reasons behind women's low labour force participation rates reside in the severe deficits of decent work in the private sector, low salaries, a lack of national child care systems, the limited availability of safe, reliable and affordable public transport systems, unsafe environments, and the lack of productive job opportunities that match women's educational attainments. These reasons help explain why women have tended towards employment in the public sector, which is undergoing major downsizing as a result of cuts to spending also promoted by the IMF. Factored together, these policies undermine women's most important employer without securing alternative decent working opportunities. Here it is worth noting that in the Egypt programme, the structural benchmarks included a goal of increasing public spending on public nurseries, which is a good example of what the IMF can and should be promoting.

This paper concludes that IMF policy in Egypt, Tunisia and Jordan must integrate issues of inequality, redistribution and gender in the MENA region at its core to ensure no negative impacts on gender, and indeed to ensure a positive contribution to the challenge of gender inequality. Austerity measures, such as cutting subsidies, substituting universal social protection systems with social safety nets, reducing public spending, and increasing indirect taxation worsen structural inequality and ultimately have disproportionate effects on women. To avoid the negative impact of macroeconomic policies on women, it is crucial to assess the actual and potential impacts of macroeconomic policies and conditionalities within the IMF loan programme. The Fund needs to go beyond policies encouraging women's labour force participation and must systematically consider the impact of its programmes on inequalities, as well the productive and reproductive spheres. This will ultimately lead to an integrated gender perspective in the design of everything the IMF does in the MENA region.

The cases of Egypt, Jordan and Tunisia add to the body of evidence indicating the IMF can do much more to translate its shift in new research discourse into its loan programmes with countries. 
Following the popular uprisings in 2011, the International Monetary Fund (IMF) ramped up its engagement in the Middle East and North Africa (MENA) region under the framework of the Deauville Partnership, which was launched by the G8 in 2011 to 'support democratic transition' in MENA. Within this framework, the IMF was reintroduced in Tunisia in the wake of the economic crisis after the revolution, as the country was facing political and economic uncertainties as well as an acute current external account deficit. ${ }^{1}$ Similar conditions were present in Jordan, where external deficits widened to $12 \%$ of GDP in $2011 .{ }^{2}$ IMF programmes were being implemented at the same time as the Syrian crisis was intensifying, leading to significant influx of refugees to Jordan and propelling the need for a humanitarian response. This constituted another challenge to Jordan, which needs to address the long lasting inequalities that predated these developments. Later, in 2016, Egypt faced a foreign reserve crisis that required the intervention of the IMF. ${ }^{3}$ Since 2012 , Jordan has received around $\$ 2.3 \mathrm{bn}$, Tunisia \$3.1bn and Egypt about \$12bn in IMF loans. The programmes in the three countries required fiscal consolidation, labour market measures and tight monetary policies. Although the issue of women's labour force participation was included in the case of Jordan and Egypt, the policies in the three countries did not systematically address either gender inequality or income redistribution.

This paper is concerned with the impact of IMF programmes on gender and economic inequalities as these two dimensions are intimately related and affect each other. Those who are most affected by macroeconomic policies, especially policies based on austerity measures, are people at the bottom of the economic ladder, where women are disproportionally affected due to already existing and entrenched gender-based discrimination and inequalities.

It is important to analyse the gendered impact of macroeconomic policies on women's rights, particularly those policies predicated or inspired by the $\mathrm{IMF}^{4}$ in the frame of its loan programmes with Tunisia, Egypt and Jordan. Mainstream macroeconomic policies are not gender-neutral; on the contrary, they are arguably biased against women. ${ }^{5}$ They affect women differently from men due to the gendered relations of power that shape economic systems in both the productive (labour market) and reproductive (home and family) spheres. ${ }^{6}$ This examination is vital, not only because these countries have a long history with the IMF, starting with the structural adjustment programmes in the late $1980 \mathrm{~s},{ }^{7}$ but more importantly because they are in a region with the lowest participation of women in the labour market in the world, standing at $20.2 \%$ for MENA as a whole and at $17.7 \%, 23.7 \%$ and $26.6 \%$ in 2018 for Jordan, Egypt and Tunisia respectively. ${ }^{8}$ This fact has shaped the understanding of macroeconomic policy in relation to gender and women's rights by narrowing it to the labour market and how to get more women to be employed in paid work. This has been the gender lens of the IMF loan programmes with respect to Egypt and Jordan. ${ }^{9}$

The need for such analysis is also highlighted by the fact that women are in the minority in parliaments (15\% in Jordan and Egypt), in the context of the decreasing influence of legislative bodies in MENA countries. Women are also absent from the key ministries, namely finance and economy, that engage in discussions with the IMF. Furthermore, the shrinking civic space in these 
countries, particularly in Egypt and Jordan, has undermined the ability of civil society organizations (CSOs) and unions to influence decision makers. Indeed, governments are failing to represent the interests of those most affected by austerity policies in their discussions and agreements with the Fund.

There have been some positive developments in terms of the IMF's introduction of specific structural benchmarks related to women; however, a focus on these risk omitting or overlooking other policies advised by the IMF that disproportionately impact women. Indeed, the very low female labour force participation rates in these countries do not mean that women do not work. In Egypt, women spend on average 30.25 hours a week on unpaid care work (compared with 4.19 for men), the value of which is estimated at around $25 \%$ of GDP. ${ }^{10}$ In Tunisia, it is estimated that women spend 5.16 hours per day on housework, compared with just 39 minutes for men. ${ }^{11}$ Thus, it is crucial to assess the actual and potential impacts of macroeconomic policies and conditionalities within the IMF loan programmes on women beyond labour force participation, and to analyse their effects in both reproductive and productive spheres in Egypt, Jordan and Tunisia.

\section{ECONOMIC INEQUALITY, GENDER INEQUALITY AND THE IMF}

Assessing the gendered impact of IMF loan programmes in these three countries is also particularly significant as gender inequalities are exacerbated within a context of acute economic inequality. According to the World Inequality Database, the share of income accruing to the top $10 \%$ reached $48.5 \%$ and $47.5 \%$ in Egypt and Jordan respectively in 2016, while the share of income going to the bottom $50 \%$ of the population does not exceed $18 \%$ and $17 \%$, respectively. ${ }^{12}$ Inequality in the region and in these countries is deeply gendered, as women tend to be concentrated in the lowest-paid jobs and those with little security. For instance, in Tunisia, $9.1 \%$ of employed women are engaged in informal employment in the formal non-agricultural sector, compared with $4.4 \%$ of men. In Egypt, $68.8 \%$ of women in informal employment are contributing family workers, while this is the case for only $8.5 \%$ of men. ${ }^{13}$. The gender gap in income is also stark; for example, in Jordan, female-headed households earn 15\% less than male-headed households, and nearly $46 \%$ of their income is from transfers and only $31 \%$ from paid work. ${ }^{14}$ Furthermore, the absence or inadequate provision of universal basic services - notably healthcare, education and transportation - not only deepens inequality and poverty but also exacerbates gender inequalities. ${ }^{15}$

Over the past few years, the IMF has come to explicitly recognize the importance of economic and gender inequality and their impact on growth. Recent research by the Fund has found that inequality is harmful, and income redistribution through progressive taxation can boost growth. ${ }^{16}$ While there is strong discourse and even operationalization guidance on gender and economic inequality, this big turnaround in research findings has yet to have made much of an impact on the way the IMF is acting at country level and in the agreements it has made with governments. When things have changed, this has largely been by introducing more focus on compensating losers from economic reforms, rather than questioning those reforms in the first place. 
Similarly, the Fund has affirmed the link between economic and gender inequalities but it has as yet, especially in the countries in question, to move beyond exclusively focusing on labour force participation when addressing gender inequalities to include redistribution policies, universal access to public services and other relevant policies.

As identified in its policy notes on operationalizing inequality issues and gender issues, the Fund maintains that these are addressed when they are deemed by country teams to be macro-critical to growth and stability. This approach falls short of recognizing that many IMF-supported policies themselves systemically impact income and gender inequalities, as is shown below. The Fund therefore needs to reverse this approach and all IMF economic advice needs to have at its core a robust gender analysis with the aim of reducing gender inequality. ${ }^{17}$

\section{FISCAL CONSOLIDATION}

\section{A. CUTTING SUBSIDIES: WHY WOMEN PAY THE PRICE}

A landmark policy and structural benchmark espoused by the IMF in the three countries is the removal or reduction of subsidies, notably on fuel and energy. Such measures have a direct effect on the wellbeing and livelihoods of people, and women in particular. They translate directly into a decrease in real income, which can manifest in different ways. So far, the way the IMF has described subsidies has been almost uniformly negative and one-sided, reflecting ideological bias. They cite the large body of research that can be found on the regressivity of subsidies. Yet, there is little analysis of their gendered effects, particularly of their removal, or of their impact on absolute poverty levels. While the relatively better off benefit more from a subsidy, for example on fuel, subsidies can still be hugely important to the incomes of the poorest. Indeed, removing subsidies can worsen inequality and poverty by raising household expenditures, especially in terms of transportation, cooking and heating, and by increasing the production cost of many items, especially food. This can have a disproportionate effect on low-income groups, ${ }^{18}$ especially women in poorer households. This is recognized by the IMF, as it insists on compensating lowincome households with targeted safety nets (see the next section).

In Jordan, the authorities removed general subsidies in 2012, which increased retail prices for gasoline by $14 \%$, liquid petroleum gas (LPG) by $54 \%$ and kerosene by $33 \% .{ }^{19}$ This led to mass protests ${ }^{20}$ which occur every time subsidies are lifted; this happened in 1989, in 1996 when bread subsidies were scrapped and fuel and electricity prices increased as a result of IMF conditions, as well as in 2018 and in May 2019. To compensate, the government instated an annual cash payment for only 33 JD (around US $\$ 45$ ) for a number of Jordanians and Gazan children of Jordanian women whose annual income does not exceed 6000 JD (around US $\$ 8,462) .{ }^{21}$ It is worth noting that the IMF declared that it opposed the lifting of bread subsidies in 2018; nevertheless, it is often the case that the austerity framework supported by the IMF has paved the way for governments to go ahead with such a measure, with or without the Fund's blessing. Similar measures were introduced in the structural benchmarks for Tunisia and Egypt, 
mainly the removal of energy and fuel subsidies. The latest price increases in Tunisia were in 2018 and 2019, and prices are likely to increase further to meet the structural benchmarks set by the IMF's Extended Fund Facility (EFF) to implement a quarterly application of automatic price adjustment. ${ }^{22}$ In Egypt, the lifting of subsidies has led to a cumulative increase in electricity bills for the poorest and middle-income families by $218 \%$ and $271 \%$ respectively since $2011 .{ }^{23}$ Skyrocketing electricity bills might result in households using less energyconsuming and time-saving appliances (like washing machines), which risks increasing the time women spend on unpaid housework. The measures also contributed to inflation, whereby households have seen the prices of fruit and vegetables rise by more than $203 \%$ between July 2014 and May 2019. ${ }^{24}$ Furthermore, the metro ticket fare in Cairo has increased by $600 \%$ in the past year. $^{25}$

The abovementioned measures could have detrimental effects on poverty. Indeed, the CRES (Centre de Recherches et d'Etudes Sociales) in Tunisia found that energy subsidies contribute to the reduction of poverty incidence by 2 points, compared with 1.56 for the existing cash transfer programme. ${ }^{26}$ Moreover, lifting subsidies in an irresponsible way can have adverse effects on women, especially when it comes to fuel products which are used for cooking. In Egypt, the price of LPG, which is used in households, has increased by $712 \%$ since $2014 .{ }^{27}$ This might lead women to switch to alternatives that can be harmful to their health. ${ }^{28}$ Fuel price increases will also affect women's mobility, especially in countries where the public transportation system is already very limited, as in Jordan (buses and cars are the prevailing means of transport), or as in the case of Egypt, where the metro offers women a safe transport option (due to the presence of women-only carriages) but the recent fare increases could price it out of reach.

The above is not meant to deny the regressivity of fossil fuel subsidies as well as their harmful impact on the environment. ${ }^{29}$ Our climate crisis demands an end to fossil fuel support, and indeed subsidies are a major concern (especially in rich countries); however, it is of absolute importance that the removal of such subsidies is managed carefully and gradually in a targeted way in countries where even slight changes in prices can have devastating effects on the poor. It is of critical importance to strengthen social protection systems based on the principle of universality prior to phasing out of subsidies. Additionally, investments and efforts should be directed towards developing clean energy alternatives and making them accessible and affordable for the poor.

\section{B. WHY 'SAFETY NETS' ARE NOT THE ANSWER}

The IMF's preferred mitigation measure to cushion the impacts of fiscal consolidation on the poor is the expansion of so called social 'safety nets'. The logic is straightforward: eliminate the spending accrued to the 'non-poor' by removing subsidies, and reinvest it in targeted safety nets to compensate 'the poor'. These measures feature in the structural benchmarks of the programmes for all three countries.

In Egypt, the Karama and Takaful programmes - established in 2015 with the support of the World Bank and identified by the IMF for support to accompany the reforms it backed - aimed to reach 1.7 million households as well as increasing the amount of cash transfers. ${ }^{30}$ They exceeded the goal, as the programmes now 
reach 2.5 million households; however, this is also due to more people becoming eligible for support, which is a reflection of deteriorating social conditions in Egypt. ${ }^{31}$ Human rights groups in Egypt have raised concerns about the scope, efficacy and distributive effects of Takaful and Karama, finding them to be inadequate to protect the right to social security and to a decent standard of living. For example, Egypt Social Progress Indicators find that cash transfer programmes (including Takaful and Karama) are estimated to cover only $49 \%$ of the population living in poverty. ${ }^{32}$ Even though resource allocation to Takaful and Karama has increased (partly due to their integration of other social security programmes, such as pension funds), ${ }^{33}$ this is unlikely to be adequate to meet increased need, as the official poverty rate has increased.

In Jordan, the IMF supported the government's effort with the World Bank to double the coverage of existing cash transfer programmes. The same is true for Tunisia, where the IMF-backed programme initially contained structural benchmarks on protecting the vulnerable, including the extension of a national programme of assistance to vulnerable families. It is important to note that Oxfam does not support the language of 'safety nets' as this implies a minimalist nonrights based understanding, but rather calls for social protection as an inalienable right of every human.

Clearly, the shift from the universality of subsidies to a targeted safety net approach is not without its problems, for three main reasons. First, means-tested targeting is 'notoriously difficult and often fails to reach the poorest people'; 34 targeting of such programmes is not very accurate. In Tunisia, there are 'leakages to non-poor of nearly 60 percent of the existing cash transfer', ${ }^{35}$ while in Jordan, the poorest $30 \%$ of the population constitute only $45 \%$ of the beneficiaries. ${ }^{36}$ In addition, accessing such programmes can be difficult for women. This is witnessed in Jordan, where just $1.27 \%$ of women-headed households receive assistance from the National Aid Fund (NAF), compared with $5.93 \%$ of households headed by men. The difference is starker when looking at social assistance in general, where $52 \%$ of women-headed households do not receive any assistance, whether from NAF or other agencies, compared with $8 \%$ of maleheaded households. ${ }^{37}$ It is also necessary to consider that gendered power dynamics within households often render men in control of such additional resources, especially when women are not engaged in paid work. ${ }^{38}$

Second, the removal of universal subsidies in favour of targeting the most vulnerable people presupposes that society is composed of poor and non-poor, rendering middle-class women invisible. This is important in the context of countries like Egypt, Jordan and Tunisia, where the bulk of social transfers and social protection schemes is based on formal employment, which is dominated by men. Finally, the use of safety nets reinforces the compensation approach used by the IMF, as they are barely redistributive, failing to address the structural causes of inequality, and have not succeeded in alleviating or reducing poverty in the three countries. The latest household income and expenditure surveys in Egypt and Jordan show that poverty increased from $27.8 \%$ in 2015 to $32.5 \%$ in 2018 for the former, ${ }^{39}$ and from $14.4 \%$ in 2010 to $15.7 \%$ in 2018 for the latter, with unofficial reports estimating it to be above $20 \% .{ }^{40}$ As for Tunisia, there is an increasing perception that poverty has risen since the last official figures of 2015, which indicated that the rate is $15.2 \%$. A recent CRES study has estimated that the poverty incidence in Tunisia has now reached $28 \% .{ }^{41}$ Moreover, these measures target those who are defined as extremely poor, and nevertheless 
ignore the vast majority of the population who live on very little but are often dropped out of targeted safety net programmes. For instance, the poverty headcount ratio for Egypt at US $\$ 5.5$ a day in 2015 reaches a staggering $62 \%$ of the population. ${ }^{42}$

Another feature underlying these interventions consists of the fundamental challenge that lies in the choice of making benefits conditional, as opposed to unconditional: the position of Oxfam and also espoused by the Sustainable Development Goals (SDGs) and the International Labour Organization (ILO) through the social protection floor framework. In the three countries, conditional cash transfers (CCTs) based on school attendance place a heavier burden on women, who become responsible for making sure that children attend school and subsequently are held responsible when the condition is not met and a source of income is lost. ${ }^{43}$ This can be a trigger for gender-based violence. These programmes are inspired by CCTs in Latin America that have gained traction; nevertheless, the success of such programmes relies on women's invisible work and they 'seem to reinforce the traditional division of labour by discouraging men from caregiving while they overburden women whose (paid and unpaid) inputs into household survival have diversified and intensified in many countries'. ${ }^{44}$ In this regard, conditionality is opposed to a rights-based approach to social protection, not to mention that it undermines the dignity of recipients, most often women, as there is an underlying assumption that they would not make wise decisions without the conditions.

\section{PRIORITIZING AUSTERITY AND DEBT REPAYMENT OVER SOCIAL SPENDING}

Social spending and investment in public healthcare, education and social protection is a powerful tool to reduce inequalities in general and gender inequalities in particular. ${ }^{45}$ The same conclusion has been reached by IMF research, recognizing that 'investments in education and health can help reduce income inequality over the medium term, address the persistence of poverty across generations, enhance social mobility, and ultimately promote sustained inclusive growth. Yet many countries still have sizable gaps in education and health services. Closing these gaps will also help address inequalities in other dimensions, such as gender and regional disparities. ${ }^{46}$ Nevertheless, this conclusion has not materialized in the three countries in question. While the IMFsupported programmes had indicative targets for social spending floors, particularly for Jordan and Tunisia, expenditures on social services were cut. As noted in previous work by Oxfam, social floors are not ambitious goals and seem to be set arbitrarily, without setting targets for the different social sectors. Most importantly, they are not mandatory. Notably, these targets are only quantitative and do not specify qualitative change and improvement in social sectors. The Stand-By Arrangement (SBA) and EFF reviews for Jordan and Tunisia show that the countries often fail to meet the social spending indicative targets; indeed, evidence shows that social spending has declined. In Tunisia, the share of education in the public budget decreased from $26.6 \%$ in 2011 to $17.7 \%$ in 2019 , and the share of health expenditures declined from $6.6 \%$ in 2011 to $5 \%$ in $2019 .{ }^{47}$

Public services have also been deteriorating in Tunisia, with more people turning to private sector services, thus deepening inequality in access to quality services and increasing out-of-pocket costs. In Tunisia, enrolment in public schools has 
decreased by $8 \%$ since 2010 , while it has increased by more than $37 \%$ in private schools. ${ }^{48}$ In Egypt, government expenditure on health as a percentage of GDP has fallen from $1.63 \%$ in 2015 to $1.35 \%$ in 2016 (below the 3\% set by the constitution). ${ }^{49}$ The same has happened in Jordan, where public health spending has declined from $5.6 \%$ of GDP in 2011 to $3.4 \%$ in $2016 .{ }^{50}$ However, the opposite pattern has been occurring when it comes to debt servicing.

The increase in interest rates as a result of monetary tightening advised by the IMF affects the price of borrowing by the government among others, especially considering currency devaluation. For instance, the Tunisian Observatory of Economy estimates that the exchange rate effect and debt interest are the major causes of budget deficit and the soaring public debt. ${ }^{51}$ Indeed, following the measures implemented by the government in mid-2016 as part of the prior actions to the EFF with Tunisia, aimed at increasing exchange rate flexibility, public debt increased significantly. Since then, the exchange rate effect had the most impact on debt accumulation. In 2015, the primary budget deficit contributed to 2 billion Tunisia Dinar in the public debt increase, and the exchange rate contribution was a little below one billion Tunisian Dinar. In 2018, the primary budget deficit's contribution fell to 1.8 billion Tunisian Dinar, while the exchange rate contribution rocketed to 9.4 billion Tunisian Dinar. During the same period the external public debt doubled from 29.9 billion to 60.2 billion Tunisian Dinar ${ }^{52}$.

A similar trend was observed in Egypt where 'sustained increase in real interest rates or an abrupt depreciation of the pound could result in adverse public debt dynamics', according to an IMF report. ${ }^{53}$ The same report estimated that in 2017 depreciation contributed by 6.5 percentage points to the change in public debt compared with primary deficit, which contributed by only 2.5 percentage points. ${ }^{54}$

The increase in public debt has contributed to shifting public expenditure for debt servicing. For instance, debt servicing nearly doubled in absolute terms in Tunisia between 2012 and 2018, and the share of interest payment of total public expenditures rose from $18 \%$ to $21 \%$, while the share of subsidies fell from $16 \%$ to $13 \% .{ }^{55}$ As for Jordan, the share of interest payments rose from $8 \%$ to $12 \%$ between 2012 and 2018, while that of subsidies of public expenditures declined from $7 \%$ to $2 \%$ in the same period. ${ }^{56}$ This trend is even more striking in Egypt, where debt servicing represented $30 \%$ of total government expenditure in FY $2016 / 2017 .{ }^{57}$ Concerningly, the lion's share of public debt is controlled by Egyptian banks, where it is estimated that each $1 \%$ increase in interest rates is equivalent to an additional 16 to 20 million Egyptian pounds in interest payment. ${ }^{58}$ This regressive redistribution is striking when looking at the public expenditures. Between 2015 and 2018, the share of budget expenditures on wages and subsidies declined from $26 \%$ to $19 \%$ and $25 \%$ to $22 \%$ respectively, while the share of interest payments increased from $30 \%$ to $38 \%$, representing an increase of $122 \%$ in absolute value. ${ }^{59}$ This points to the shifting priorities in public expenditures and a redistribution of wealth from the public - especially women, who benefit the most from wages and subsidies - to creditors.

This supports what has already been pointed out by Oxfam: in the frame of IMFsupported programmes, countries are confronted with 'conflicting targets: typically, cutting budgets or maintaining fiscal stability while preserving expenditure in critical areas. As the former is a binding condition, it is often prioritized at the expense of the latter. ${ }^{60}$ 


\section{THE GENDERED IMPACT OF TAX REFORMS}

To meet the increasing debt service and to curb public deficits, the IMF supported tax reforms aimed at increasing revenue. However, these tended to be regressive, relieving high-income groups and corporations from paying the price of fiscal consolidation. For example, in Tunisia, the IMF explicitly supported 'tax measures to shift the burden towards indirect taxation'. ${ }^{61}$ As a result, VAT rates increased in 2018 from $18 \%, 12 \%$ and $6 \%$ to $19 \%, 13 \%$ and $7 \% 6263$. The Fund also called for exemptions on VAT in Tunisia, without specifying which goods should be exempt and whether it would target basic food products. At the same time, the Fund explicitly supported the removal of exemptions on many basic goods for the General Sales Tax.

Egypt adopted a VAT rate of $13 \%$ in 2016 based on the recommendation of the IMF. As a prerequisite for signing their loan with the IMF, ${ }^{64}$ the rate was increased to $14 \%$ and includes exemptions on basic food items. Although exemptions can lessen the incidence of VAT, they are not enough to protect the most vulnerable from feeling its impacts, especially in contexts of high inflation, such as in the countries in question. ${ }^{65}$ The Fund claims that 'revenues raised by the VAT bill will free up resources for social spending', ${ }^{66}$ but this has not materialized, as shown above. Furthermore, it has been widely established that VAT is a regressive tax, meaning it is disproportionally borne by the poor and lower income groups because the same rate is levied 'on rich and poor consumers alike, resulting in a greater percentage of income being spent on tax by low income earners than high-income earners'. ${ }^{67}$ Also, the gender bias of VAT is well recorded. This is due to the fact that women generally earn less and have lower incomes than men. Women also tend to spend proportionally more on food and other consumables for their households due to their greater burden of unpaid care work. In addition, feminine products related to sexual and reproductive health are not exempted from VAT. ${ }^{68}$ Indeed, if gender differences are not considered from the outset, VAT can also be discriminatory towards women. ${ }^{69}$

On the other hand, the Fund has supported progressive reforms in boosting direct taxation, notably in Jordan where corporate income tax (CIT) was increased in many sectors, including applying CIT in free economic zones and increasing the taxation of interest on income from $5 \%$ to $7 \%$, as well as reforms to personal income tax. These efforts need to continue and to push for more progressivity. In Egypt, the IMF has recognized the need to increase the progressivity of PIT, strengthening compliance as well as addressing profit shifting by companies and reconsidering tax incentives for foreign direct investment and free zones. These measures are yet to be implemented. Strengthening progressivity in direct taxation coupled with redistributive spending would decrease inequalities, and gender inequality in particular, as they would target higher-income earners and corporations, where men are more present than women. 


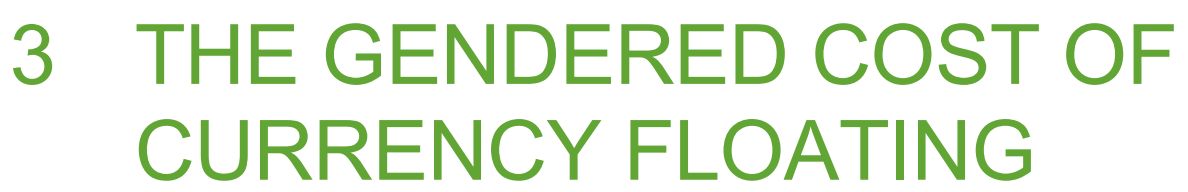

While it has supported the exchange rate peg to the dollar in Jordan, the IMF in Egypt and Tunisia supported exchange rate liberalization and flexibility, which led to currency devaluation. According to Christine Lagarde, former IMF managing director, 'the liberalization of the exchange rate regime and the devaluation of the Egyptian pound were critical steps toward restoring confidence in the economy'. ${ }^{70}$ In the same vein, in the SBA programme (2013-2015) for Tunisia as well as in the frame of the subsequent EFF, the IMF supported 'greater exchange rate flexibility'. ${ }^{71}$ The objectives of such measures are the increase of foreign reserve buffers as well as to render the economy more competitive on the external market. ${ }^{72}$ Nevertheless, the immediate and continued impacts of these policies are mainly high inflation rates and consequently, the significant decrease in purchasing power. ${ }^{73}$ This is of the utmost importance as both Egypt and Tunisia are net importers of basic food items and health products among others. Between June 2013 (at the start of the SBA) and July 2017, the Tunisian Dinar lost $49 \%$ of its value ${ }^{74}$ while inflation has skyrocketed in recent years to reach its peak of $7.7 \%$ in May 2018. ${ }^{75}$ Foodstuff inflation reached its peak of $8.3 \%$ in February 2019 , while inflation related to school supplies is steady at $10 \%{ }^{76}$ In Egypt, yearto-year inflation of the price of fruit and vegetables reached $24 \%$ in June $2019 .{ }^{77}$

These price increases have direct effects on women, and especially on womenheaded households, by using up more of their budgets. As mentioned above, due to prevailing social norms and the gendered division of labour, women usually take care of buying household supplies; price increases can lead to deepening their time poverty as they have to spend more time bargaining and shopping around for cheaper products and alternatives or resort to making some products themselves if possible. This burden is usually absent from the prevailing analysis. Indeed, as Elson affirms, 'the elasticity of women's labour is taken for granted and under-acknowledged, even though the time burdens they face render them a frequently over-utilized rather than an under-utilized resource'. ${ }^{78}$

Depreciation-induced inflation not only increases women's unpaid workload and forces them to adopt some negative coping mechanisms to cope with daily expenses. It can also have an impact on women's reproductive and sexual rights and health. Currency devaluation increases the cost of imported intermediate goods and finished imported products such as contraceptives and sanitary pads. The currency devaluation in Egypt has caused shortages of medicine, including contraceptive pills of all kinds. ${ }^{79}$ Pharmaceutical companies feared not making reasonable profit margins following the devaluation of the Egyptian pound, and as a result, a black market developed for contraceptive pills. This has had detrimental effects on women's sexual rights, as for two years a popular over-thecounter morning-after pill was difficult to find. Thus, pharmacies would send women away empty-handed, making them ask around for pills. This risked exposing women in a highly conservative society at best, and at worst forcing them to take unsafe decisions to avoid such exposure. ${ }^{80}$ Even though these contraceptives are now available, their price has significantly increased. In Tunisia, a shortage of contraceptives and IUDs has also been witnessed, mainly due to the inability of the Central Pharmacy to pay for these imports because of 
currency devaluation. On 11 July 2019, several CSOs in Tunisia, including Oxfam, issued a statement calling on authorities to stop the deterioration in women's sexual and reproductive healthcare and rights. ${ }^{81}$

\section{WOMEN IN THE LABOUR MARKET}

\section{A. THE ROAD TO WOMEN'S UNEMPLOYMENT}

The IMF has explicitly called for and supported much-needed measures to raise female labour force participation rates in Egypt and Jordan. ${ }^{82}$ In the Egypt programme, the structural benchmarks even included a goal of increasing public spending on public nurseries, ${ }^{83}$ thus recognizing the impact of unpaid care work on women in terms of access to paid work. In Jordan too, the Fund's programme is supporting the government's efforts to make nurseries available for women in the labour market, especially those working in small and medium-sized enterprises (SMEs). This is important, as workers in SMEs, and particularly women, often lack decent work conditions due to the small size of the establishment and its limited capacities. The Fund has been also promoting gender budgeting in the region, nevertheless it needs to operationalize it in its programmes. These developments are on the right track and should be part of a deeper and more systematic integration of gender issues in the Fund's programmes.

Nevertheless, the IMF's stated objective of supporting women's employment is undermined by one of the most central aspects of IMF supported policies in all three countries, i.e. reducing the size of the public sector, the main employer of women, by limiting public sector employment and cutting the wage bill. This constitutes a conditionality in Jordan and Tunisia loan programmes and can be viewed as an outcome of several policies in Egypt. In Jordan, $45 \%$ of paid women employees were working in the public sector in $2018,{ }^{84}$ and in Tunisia the share stood at $24.5 \%$ in $2014 .{ }^{85}$ In Egypt, $42.4 \%$ of employed women were working in the public and governmental sector in $2018 .^{86}$ The Fund claims that 'high public employment has discouraged labour force participation. Higher public employment has been associated with lower labour force participation, globally and in the region, especially among women. ${ }^{\prime} 77$ The reason for this, according to the IMF, is that better-paying and protected jobs in the public sector that grant benefits to all the family may discourage other members of the family, especially women, from seeking paid jobs to provide a secondary income. ${ }^{88}$ This implies that reducing public sector jobs and loosening the protection (and rights) they afford would encourage women to enter the labour market because they would have to do so in order to compensate.

Experience of IMF programmes in these countries shows us that limiting public sector employment will disproportionately affect women as it is their first choice of employment. Unlike in other regions, in MENA women are more likely than men to be found in formal employment. In North Africa, $41.5 \%$ of women work in the informal economy, whereas the figure is $68 \%$ for men. ${ }^{89}$ This is because women 
seek the public sector as it grants them formal jobs with better working conditions. ${ }^{90}$ In many instances, it is their first and only choice where withdrawing from the labour market or waiting for a public sector opportunity are opted for rather than seeking employment in the private sector. Indeed, 'long-term unemployed females are holding out for a government job but have little desire or inclination to accept a job, especially an informal job, in the private sector, which is usually what is available to them'. ${ }^{91}$ Thus, the IMF policies of reducing the public wage bill might block the path of many women to public employment and push them towards the private sector, which is mostly informalized and offers little to no protection.

In Egypt, several measures were adopted to downsize public sector employment and reduce the wage bill, such as the Law 18 of 2015 to decrease the wage bill granted the state the power to terminate employment within a six-month probation period, and to relocate an employee subject to a salary reduction. This particularly affects women, ${ }^{92}$ not only because they are present in the public sector, but also because forced relocation might compel them to leave their job as they don't have the power to move their family with them. Furthermore, the government might choose to lay off women instead of men in the public sector as women are not considered to be the breadwinners. More women moving to the private sector is likely to increase the gender pay gap in Egypt, as women in the private sector earn $35 \%$ to $40 \%$ less than men. ${ }^{93}$ Although these measures were taken before the start of the loan programme, the IMF welcomed them, stating that these reforms 'regarding public sector pay and hiring practices will help reduce labour market distortions' ${ }^{94}$ Recently, Tunisia imposed a hiring cap of 3,000 in the public sector (this would only replace $25 \%$ of vacancies resulting from retirement). ${ }^{95}$ Such measures can also cause the proliferation of informal employment in the public sector, as the government has to hire based on precarious contractual arrangements, as seen in the public education sector in Tunisia.

\section{B. THE PRIVATE SECTOR AT ALL COSTS}

The IMF-supported measures aim to encourage women to access the labour market, particularly the private one. Thus, they are accompanied by policies aimed at supporting private sector development. However, limiting the issue of women's employment to encouragement and flexible working arrangements for care responsibilities is not enough, for several reasons. Unemployment in these countries is relatively high, especially among women. In Jordan, unemployment reached $18 \%$ overall and $23.3 \%$ among women in $2018 ;{ }^{96}$ in Tunisia it stood at $15.4 \%$ overall the same year, going up to $22.7 \%$ for women; ${ }^{97}$ while for Egypt, unemployment reached $8.9 \%$ overall and $19.6 \%$ for women. ${ }^{98}$ These numbers are alarming, and without addressing the structural reasons for unemployment related to economic policies that have been unchanged for decades, women who want to enter the labour market are more likely become unemployed. This is added to the prevailing patriarchal social norms that relegate women's employment to a secondary position in favour of their ascribed gendered roles, mainly unpaid care work. Thus, employers might simply choose not to hire women.

Furthermore, the ongoing IMF-supported programmes identify 'skills mismatches' as one of the main reasons for unemployment, saying that this could be 
addressed through vocational training and education. However, this assertion overlooks the informalization of the economies in the three countries and the high incidence of informal employment. Also, the reasons behind women's low labour force participation rates reside in the fact that dominant socio-cultural norms in the region do not recognize women as legitimate economic actors or even actors in the public sphere in their own right. Women's paid employment is deemed in many instances as a last resort in situations of economic difficulties facing the household. It could also be explained by the severe deficits of decent work in the private sector, low salaries, lack of national child care systems, availability of safe, reliable and affordable public transport systems, unsafe environments, and the lack of productive job opportunities that match women's educational attainments. ${ }^{99}$ For instance, in all three countries, maternity leave in the private sector is shorter than in the public sector and private establishments often grant less than what is legally required. In Egypt, a 2012 labour market survey indicated that $75 \%$ of women have contracts for one year or less, and $17.5 \%$ do not have a contract at all. ${ }^{100}$ In Jordan, women in the private sector often leave the labour market after marriage, unlike those employed in the public sector. A survey revealed that $78 \%$ of women who withdrew from the labour market were married and $86 \%$ were working in the private sector, compared with $9 \%$ in the public sector. ${ }^{101}$ This indicates that boosting private sector attractiveness for women will not be achieved through lowering employment conditions and benefits in the public sector but by guaranteeing decent working conditions and protection in the private sector to be at par with public employment. Under the current circumstances 'If the possibility of public sector appointments were to completely disappear, most of these [unemployed] women would essentially be classified as out of the labour force'. ${ }^{102}$

Finally, the International Trade Union Confederation (ITUC) global rights index classified Jordan as country where there are regular violations of rights; Tunisia as one where there are systematic rights violations; and Egypt as a country where there is no guarantee of rights. Particularly, Egypt and Jordan do not guarantee freedom of association and impose heavy restrictions on union organizing. This poses another obstacle for women to collectively influence policies and mobilize for their rights. 


\section{CONCLUSION AND RECOMMENDATIONS}

This is far from being an exhaustive account of the gendered impact of IMFinspired or recommended policies in the MENA region. The IMF must recognize that such impacts are present beyond the issue of access to the labour market for women. The austerity measures imposed take their greatest toll on women, especially in the reproductive sphere. Failure to recognize this fact can lead to those women experiencing 'social depletion [...] when there is a critical gap between the outflows - domestic, affective and reproductive - and the inflows that sustain their health and well-being. This affects not only individuals but also the households and communities in which social reproduction takes place.' ${ }^{103}$ Thus, the impact of macroeconomic policies can be detrimental to women's wellbeing and health. Based on the above, Oxfam recommends that the IMF builds on its ongoing efforts to integrate gender equality in its programmes. It should:

- Recognize that conventional macroeconomic policies and loan programmes are not gender-neutral, and consider their impact on women in the productive and reproductive spheres.

- Integrate a gender perspective in the design of its policies and programmes, and not only as an add-on.

- Conduct a pre- and post-impact assessment of its programmes, specifically with regards to their distributional impact as well as their effects from a gendered point of view, and include dimensions of inequality and paid and unpaid care work. Be prepared to drop or fundamentally change proposed reforms, rather than simply focus on mitigating 'safety nets'.

- Include in the country programmes clear and binding targets to reduce inequalities through redistributive policies to be agreed with citizens and different groups, especially women's rights organizations.

- Move away from shifting the tax base towards indirect taxation, enhance progressivity of PIT and CIT, and introduce property and wealth taxes in the countries in question. Also ensure it recommends VAT exemptions or zero ratings for the poorest consumers as well as for products related to women's sexual and reproductive health.

- Move away from a targeted social safety net approach to a universal social protection approach, in line with that of the ILO and 2030 Agenda for Sustainable Development.

- Ensure that loan programmes allow countries the fiscal space to achieve universalism in the provision of quality healthcare, education, childcare and elder care. In this regard, the IMF should turn social spending floors into outcome-based binding conditions which are agreed with governments and their citizens. In addition, outcomes ought to be both qualitative and quantitative.

- Encourage governments to adopt gender-sensitive legislations that can protect women in the labour force, and ensure that decent work conditions are guaranteed in the private sector for both men and women. Include women's groups, workers' unions and other CSOs in the design of social and macroeconomic policy. In order to do so and to ensure women's voices are 
heard, the IMF should ensure that its programmes are not contributing (even indirectly) to the narrowing of civic space. The IMF should support an enabling environment for public participation and indeed take measures to mitigate programme-related risks, particularly minimizing reprisals, relating to freedoms of expression, assembly, and association. 
1 IMF (2013). Tunisia: Request for a Stand-By Arrangement. Washington DC: IMF.

2 IMF (2012). Jordan: Request for a Stand-By Arrangement. Washington DC: IMF.

3 IMF (2017). Arab Republic of Egypt: Request for Extended Arrangement under the Extended Fund Facility. Washington DC: IMF.

4 For a detailed discussion on the gendered impact of IMF's fiscal consolidation policies see: K. Donald and N. Lusiani (2017). The Gendered Costs of Austerity: assessing the IMF's role in budget cuts which threaten women's rights. s.l.: Bretton Woods Project.

5 D. Elson (2013). Economic Crises from the 1980s to the 2010s: A Gender Analysis. In: S. M. Rai and G. Waylen, eds. New Frontiers in Feminist Political Economy. London: Routledge, pp. 189-212.

6 S.M. Rai and G. Waylen (2013). Feminist Political Economy: Looking Back, Looking Forward. In: R.M. Shirin and G. Waylen, eds. New Frontiers in Feminist Political Economy. London: Routledge, pp. 1-18.

7 The IMF has a long history in these three countries dating back to the last century. In 1989, Jordan signed its first Stabilization and Structural Adjustment Programmeme (SALP) under a Stand-by Arrangement. Between 1989 and 2004 Jordan signed six lending agreements (three SBAs and three EFFs). As for Egypt and Tunisia, lending agreements with IMF date back to 1962 and 1964 respectively. Nevertheless, the agreements in the late 1980s had the most profound effect on the economies. Between 1987 and 1998 , Egypt signed four loan agreements (three SBAs and one EFF), whereas Tunisia signed an SBA and an EFF between 1986 and 1988. For analysis on the impact of those lending agreements see: H. El-Said and J. Harrigan (2014). Economic Reform, Social Welfare and Political Instability in the Arab World: The Case of Jordan, Egypt, Morocoo and Tunisia 1983-2004. Middle East Journal, 68(1), pp. 99-21 and M. Mossallam (2015). The IMF in the Arab world: Lessons unlearnt, s.l.: Bretton Woods Project.

8 World Bank Group (no date). World Bank Data. [Online].

9 IMF (2018). How to Operationalize Gender Issues in Country Work. Washington, D.C.: IMF.

10 K. Tabet et al. (2019). Counting on Women's Work without Counting Women's Work: Women's Unpaid Work in Jordan, Lebanon, Tunisia and Egypt. Oxfam. https://policy-practice.oxfam.org.uk/publications/countingon-womens-work-without-counting-womens-work-womens-unpaid-work-in-jord-620811

11 lbid.

12 World Inequality Database. [Online].

13 ILO. (2018). Women and men in the informal economy: a statistical picture. Geneva: ILO.

14 Hashemite Kingdom of Jordan (no date). Population and Women Statistics in Jordan. [Online] Available (in Arabic) at: https://www.unescwa.org/sites/www.unescwa.org/files/page_attachments/mrfq1hsyt_Iskn_wlmr_0.pdf

15 M-K. Chan, et al. (2019). Public Good or Private Wealth? Universal health, education and other public services reduce the gap between rich and poor, and between women and men. Fairer taxation of the wealthiest can help pay for them. Oxfam. https://policy-practice.oxfam.org.uk/publications/public-good-orprivate-wealth-universal-health-education-and-other-public-servi620599. DOI: http://dx.doi.org/10.21201/2019.3651

16 IMF (2017). IMF Fiscal Monitor: Tackling Inequality. Washington, DC: IMF.

17 C. Mariotti, N. Galasso and N. Daar (2017). Great Expectations: Is the IMF Turning Words into Action on Inequality? Oxfam. https://policy-practice.oxfam.org.uk/publications/great-expectations-is-the-imf-turningwords-into-action-on-inequality-620349

18 I. Ortiz, M. Cummins, J. Capaldo and K. Karunanethy (2015). The Decade of Adjustment: A Review of Austerity Trends 2010-2020 in 187 Countries. Geneva: ILO.

19 IMF (2013). Jordan: First Review Under the Stand-By Arrangement. Washington, DC: IMF.

20 BBC (2012). Jordan Unrest: Clashes after Fuel Protest. BBC, 16 November.

21 The Jordan Times (2018). Government announces economic measures, cash subsidy mechanism. The Jordan Times, 16 January.

22 IMF (2019). Tunisia: Fifth Review Under the Extended Fund Facility. Washington, DC: IMF.

23 S. Hussein (2018). A Spill of Flaws: Egypt's IMF-Backed Energy Plan. Beirut: Arab NGO Network for Development.

24 B. Kassab (2019). MP: New fuel pricing mechanism 'rushed' through to appease IMF on subsidy cuts. Mada Masr, 9 July.

25 Social Justice Platform (2018). The Price of Deficit: Analaysis of the 2018/2019 Budget. s.l.: Social Justice Platform.

26 Centre de Recherches et d'Etudes Sociales (2017). Evaluation de la Performance des Programmemes d'assistance Sociale en Tunisie. Tunis: CRES.

27 B. Kassab (2019). Op cit.

28 Energia (2018). Gender and fossil fuel subsidy reform: Findings from and recommendations for Bangladesh, India and Nigeria. s.I.: Energia International Network on Gender and Sustainable Energy.

29 H. Stoddart and L. Prieg (2014). Food, Fossil Fuels and Filthy Finance. Oxfam. https://policypractice.oxfam.org.uk/publications/food-fossil-fuels-and-filthy-finance-332741 
30 C. Jarvis (2017). Protecting the Vulnerable During Egypt's Economic Reform. [Online] Available at: https://www.imf.org/external/np/blog/nafida/011817.pdf [Accessed 21 July 2019].

31 W. Ahmed (2018). Escaping the poverty cycle? 3 years of Takaful and Karama. Mada Masr, 4 April.

32 Egypt Social Progress Indicators (2018). Economic Indicators| Estimated percentage of the poor covered by cash transfer programmemes. At: https://www.progressegypt.org/en/indicator.html\#cash-transfer

33 A. Elleithy (2019). Egypt plans single cash transfer system for combating poverty. Al-Monitor, 17 July.

34 C. Mariotti, N. Galasso and N. Daar (2017). Great Expectations. Op. cit.

35 IMF (2014). Tunisia: First and Second Review Under the Stand-By Arrangement, Washington, DC: IMF.

36 Hashemite Kingdom of Jordan (2019). National Social Protection Strategy 2019-2025, s.I.: s.n.

37 Hashemite Kingdom of Jordan (no date). Op. cit

38 N. Kabeer et al. (2013). Paid work, women's empowerment and inclusive growth: Transforming the structures of constraint. s.I.: UN Women.

39 Central Agency for Public Mobilization \& Statistics (2019). Household Income and Expenditure Survey 2017/2018: Poverty Indicators. Cairo: Central Agency for Public Mobilization \& Statistics.

40 Middle East Monitor (2019). Government survey: Extreme poverty in Jordan at 15.7\%. Middle East Monitor, 9 April.

41 Centre de Recherches et d'Etudes Sociales (2017). Op. cit.

42 World Bank Group (no date). World Bank Data. [Online].

43 S. Chant and K. Brickell (2014). Domesticating (and de-patriarchalizing) the development agenda: a need for greater household (and family) engagement in gender-related policy interventions?. In: S.M. Rai and G. Waylen, eds. New Frontiers in Feminist Political Economy. London: Routledge, pp. 85-113.

44 Ibid.

45 K. Tabet et al. (2019). Counting on Women's Work without Counting Women's Work. Op. cit.

46 IMF (2017). Op. cit.

47 A. Badawi (2018). 2019 Budget: Continuing to Spread Economic Illusions to Achieve Political Dreams. Tunis: Forum Tunisien des Droits Economiques et Sociaux (in Arabic).

48 H. Lac (2018). Le système éducatif en chiffres : un secteur qui s'enlise. Inkyfada. 2 November.

49 Egypt Social Progress Indicators (2018). Economic Policy indicators Public health expenditure as a percentage of GDP. At: https://www.progressegypt.org/en/indicator.html\#public-health-expenditure

50 World Bank Group (no date). World Bank Data. [Online].

51 C. Ben Rouine (2019). Data Analyis n. 22: The Devaluation of the Dinar is Making Public Debt Explode. Tunis: Observatoire Tunisien de l'Economie.

52 lbid.

53 IMF (2019). Arab Republic of Egypt: Fourth Review Under the Extended Arrangement Under the Extended Fund Facility. Washington, DC: IMF.

54 Ibid.

55 These are calculations of the author based on the data of the Ministry of Finance.

56 Ibid.

57 Egypt Social Progress Indicators (2018). Economic Policy indicators| Debt service as a percentage of total government expenditure. At: https://www.progressegypt.org/en/indicator.html\#debt-servicing

58 S. Hussein (2018). The Inequities of the International Monetary Fund Programme in Egypt: How Monetary Policy Conflict with the Fiscal Policies Objectives. Beirut: ANND.

59 These are calculations of the author based on the data of the Ministry of Finance.

60 C. Mariotti, N. Galasso and N. Daar (2017). Great Expectations. Op. cit.

61 IMF (2017). Tunisia: First Review Under the Extended Fund Facility. Washington, DC: IMF.

62 P. Magnon (2018). En Tunisie, 2018 rime avec hausse de la TVA. Francelnfo. 6 January.

63 The different rates are: $7 \%$ on information technology services, hotels and restaurant activities, and equipment; $13 \%$ on raw materials, craft industry products, medical activities, and canned food and $19 \%$ on operations related to services and goods not subject to another rate.

64 IMF (2017). Op. cit.

65 C. Mariotti, N. Galasso and N. Daar (2017). Great Expectations. Op. cit.

66 Letter from Chris Jarvis, IMF Mission Chief in Egypt, to Mahinour el-Badrawi and Allison Corkery in response to their article Egypt's New IMF Deal Comes with a Huge Price Tag for Human Rights (see endnote 92). Center for Economic and Social Rights.

http://www.cesr.org/sites/default/files/IMFresponseEgyptnew\%20IMFdealcomeswithahugepricetagforhuman \%20rights032017_0.pdf

67 M. Buenaventura and C. Miranda (2017). The IMF, Gender Equality and VAT. n.a.: Bretton Woods Project

68 ANND (2018). Gender Inequality in the Tax Systems of Arab Countries: A Comparative Study of Lebanon, Tunisia and Egypt. Beirut: ANND. 
69 M. Buenaventura and C. Miranda (2017). Op. cit.

70 IMF (2016). Op. cit.

71 IMF (2016). Tunisia: Letter of Intent, Memorandum on Economic Financial Policies, and Technical Memorandum of Understanding. Washington DC: IMF.

72 Ibid.

73 For Tunisia see: A. Badawi (2018). 2019 Budget: Continuing to Spread Economic Illusions to Achieve Political Dreams. Tunis: Forum Tunisien des Droits Economiques et Sociaux (in Arabic); and for Egypt see: S. Hussein and A. Mekawy (2017). An Eye on Debt: First Report on the IMF Loan Programme as of April 2017. Cairo: Egyptian Initiative for Personal Rights.

74 C. Ben Rouine (2017). Op. cit.

75 Institut National de la Statsitque [Online] Available at: http://www.ins.tn/

76 Ibid.

77 Central Bank of Egypt [Online] Available at: https://www.cbe.org.eg/en/Pages/default.aspx

78 D. Elson (2013). Op.cit.

79 I. Eickhof (2018). Fear and Floating in Alexandria: The Economy, the Pound, and Women's Sexual Health. Égypte/Monde arabe, 1(17), pp. 193-216.

80 lbid.

81 S. Belhassen (2019). Non au désengagement de l'Etat Tunisien en matière de santé sexuelle et de la reproduction. Tunisie Tribune, 12 July.

82 IMF (2018). Op. cit.

83 IMF (2017). Op. cit.

84 Department of Statistics (2018). Statistical Yearbook 2017. Amman: Department of Statistics.

85 Calculations of the author based on INS data, and: Statistiques Tunisie (2016). Caracteristiques des Agents de la Fonction Publique et leurs Salaires (2010-2014). Tunis: Statistiques Tunisie.

86 Central Agency for Public Mobilization \& Statistics (2019). Quarterly Bulletin: Labour Force Survey-The

Fourth Quarter 2018. Cairo: Central Agency for Public Mobilization \& Statistics.

87 IMF (2018). Public Wage Bills in the Middle East and Central Asia, Washington, DC: IMF

88 lbid.

89 ILO (2018). Op. cit.

90 K. Tabet et al. (2019). Counting on Women's Work without Counting Women's Work. Op. cit.

91 R. Assaad and C. Krafft (2016). Labor Market Dynamics and Youth Unemployment in the Middle East and North Africa: Evidence from Egypt, Jordan and Tunisia. Economic Research Forum Working Paper Series No. 993. Cairo.

92 M. El-Badrawi and A. Corkery (2017). Egypt's New IMF Deal Comes with a Huge Price Tag for Human Rights, London: Bretton Woods Project. https://www.brettonwoodsproject.org/2017/02/egypts-new-imf-dealcomes-huge-price-tag-human-rights/

93 World Bank (2014). Egypt's Private Sector: A Driving Force for Job Creation. [Online] Available at: https://www.worldbank.org/en/news/feature/2014/09/18/egypts-private-sector-a-driving-forcefor-job-creation [Accessed 25 August 2019].

94 IMF (2015). Arab Republic of Egypt: 2014 Article IV Consultation - Staff Report, Washington, DC: IMF

95 IMF (2019). Op. cit..

96 Department of Statistics (2018). Op. cit.

97 Institut National de la Statsitque [Online].

98 Central Agency for Public Mobilization \& Statistics (2019). Op. cit.

99 K. Tabet et al. (2019). Counting on Women's Work without Counting Women's Work. Op. cit.

100 lbid.

101 lbid.

102 R. Assaad and C. Krafft (2016). Op. cit.

103 S.M. Rai, C. Hoskyns and D. Thomas (2014). Depletion. International Feminist Journal of Politics. 16(1), pp. 86-105. 


\section{OXFAM}

Oxfam is an international confederation of 19 organizations networked together in more than 90 countries, as part of a global movement for change, to build a future free from the injustice of poverty. Please write to any of the agencies for further information, or visit www.oxfam.org

Oxfam America (www.oxfamamerica.org) Oxfam Australia (www.oxfam.org.au) Oxfam-in-Belgium (www.oxfamsol.be) Oxfam Brasil (www.oxfam.org.br)

Oxfam Canada (www.oxfam.ca)

Oxfam France (www.oxfamfrance.org)

Oxfam Germany (www.oxfam.de)

Oxfam GB (www.oxfam.org.uk)

Oxfam Hong Kong (www.oxfam.org.hk)

Oxfam IBIS (Denmark) (www.oxfamibis.dk)

Observer:

KEDV (Oxfam Turkey)
Oxfam India (www.oxfamindia.org)

Oxfam Intermón (Spain) (www.oxfamintermon.org)

Oxfam Ireland (www.oxfamireland.org)

Oxfam Italy (www.oxfamitalia.org)

Oxfam Mexico (www.oxfammexico.org)

Oxfam New Zealand (www.oxfam.org.nz)

Oxfam Novib (Netherlands) (www.oxfamnovib.nl)

Oxfam Québec (www.oxfam.qc.ca)

Oxfam South Africa (www.oxfam.org.za) 